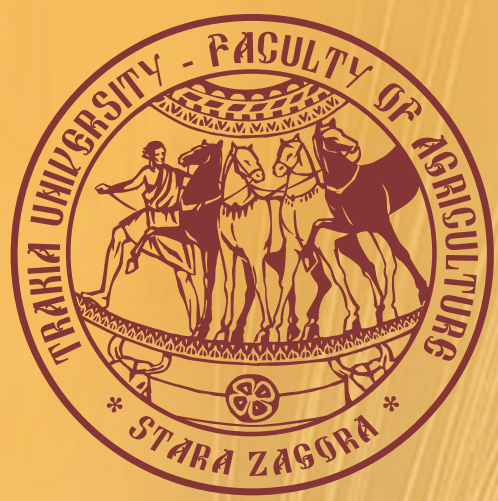

ISSN $1313-8820$ (print)

ISSN 1314 - 412X (online)

Volume 9 , Number 3

September 2017

\title{
AGRICULTURAL
}

\section{SCIENCE AND TECHNOLOGY}

\section{7}

An International Journal Published by Faculty of Agriculture, Trakia University, Stara Zagora, Bulgaria 


\section{Editor-in-Chief}

Georgi Petkov

Faculty of Agriculture

Trakia University, Stara Zagora

Bulgaria

E-mail: gpetkov@af.uni.sz.bg

\section{Co-Editor-in-Chief}

Dimitar Panayotov

Faculty of Agriculture

Trakia University, Stara Zagora

Bulgaria

\section{Editors and Sections}

\section{Genetics and Breeding}

Tsanko Yablanski (Bulgaria)

Atanas Atanasov (Bulgaria)

Svetlana Georgieva (Bulgaria)

Nikolay Tsenov (Bulgaria)

Max Rothschild (USA)

Ihsan Soysal (Turkey)

Horia Grosu (Romania)

Stoicho Metodiev (Bulgaria)

Bojin Bojinov (Bulgaria)

\section{Nutrition and Physiology}

Nikolai Todorov (Bulgaria)

Peter Surai (UK)

Ivan Varlyakov (Bulgaria)

George Zervas (Greece)

Vasil Pirgozliev (UK)

\section{Production Systems}

Radoslav Slavov (Bulgaria)

Dimitar Pavlov (Bulgaria)

Bogdan Szostak (Poland)

Banko Banev (Bulgaria)

Georgy Zhelyazkov (Bulgaria)

\section{Agriculture and Environment}

Martin Banov (Bulgaria)

Peter Cornish (Australia)

Vladislav Popov (Bulgaria)

Tarek Moussa (Egypt)

\section{Product Quality and Safety}

Stefan Denev (Bulgaria)

Vasil Atanasov (Bulgaria)

Roumiana Tsenkova (Japan)

\section{English Editor}

Yanka Ivanova (Bulgaria)
Scope and policy of the journal

Agricultural Science and Technology /AST/

- an International Scientific Journal of Agricultural and Technology Sciences is published in English in one volume of 4 issues per year, as a printed journal and in electronic form. The policy of the journal is to publish original papers, reviews and short communications covering the aspects of agriculture related with life sciences and modern technologies. It will offer opportunities to address the global needs relating to food and environment, health, exploit the technology to provide innovative products and sustainable development. Papers will be considered in aspects of both fundamental and applied science in the areas of Genetics and Breeding, Nutrition and Physiology, Production Systems, Agriculture and Environment and Product Quality and Safety. Other categories closely related to the above topics could be considered by the editors. The detailed information of the journal is available at the website. Proceedings of scientific meetings and conference reports will be considered for special issues.

\section{Submission of Manuscripts}

There are no submission / handling / publication charges.

All manuscripts written in English should be submitted as MS-Word file attachments via e-mail to editoffice@agriscitech.eu. Manuscripts must be prepared strictly in accordance with the detailed instructions for authors at the website

www.agriscitech.eu and the instructions on the last page of the journal. For each manuscript the signatures of all authors are needed confirming their consent to publish it and to nominate on author for correspondence.

They have to be presented by a submission letter signed by all authors. The form of the submission letter is available upon from request from the Technical Assistance or could be downloaded from the website of the journal. Manuscripts submitted to this journal are considered if they have submitted only to it, they have not been published already, nor are they under consideration for publication in press elsewhere. All manuscripts are subject to editorial review and the editors reserve the right to improve style and return the paper for rewriting to the authors, if necessary. The editorial board reserves rights to reject manuscripts based on priorities and space availability in the journal.

The journal is committed to respect high standards of ethics in the editing and reviewing process and malpractice statement. Commitments of authors related to authorship are also very important for a high standard of ethics and publishing. We follow closely the Committee on Publication Ethics (COPE), http://publicationethics.org/resources/guid elines

The articles appearing in this journal are indexed and abstracted in: DOI, EBSCO Publishing Inc., AGRIS (FAO) and DOAJ.

The journal is accepted to be indexed with the support of a project № BG051P00013.3.05-0001 "Science and business" financed by Operational Programme "Human Resources Development" of EU. The title has been suggested to be included in SCOPUS (Elsevier) and Electronic Journals Submission Form (Thomson Reuters).

The journal is freely available without charge to the user or his/her institution. Users can read, download, copy, distribute, print, search, or link to the full texts of the articles, or use them for any other lawful purpose, without asking prior permission from the publisher or the author.

This issue is printed with the financial support by Contract No DNP 0521/20.12.2016, financed from Fund 'Scientific Research' grant Bulgarian scientific Periodicals.

\section{Address of Editorial office:}

Agricultural Science and Technology Faculty of Agriculture, Trakia University

Student's campus, 6000 Stara Zagora

Bulgaria

Telephone: +35942699330 $+35942699446$

www.agriscitech.eu

Technical Assistance:

Nely Tsvetanova

Telephone: +359 42699446

E-mail:editoffice@agriscitech.eu 


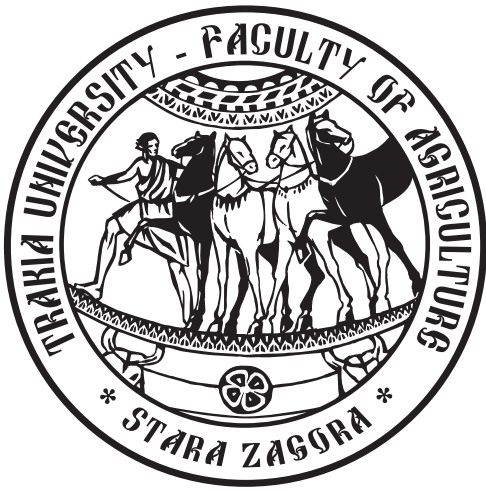

AGRICULTURAL

SCIENCE AND TECHNOLOGY

\section{7}

An International Journal Published by Faculty of Agriculture,

Trakia University, Stara Zagora, Bulgaria 


\title{
Haematological and serum biochemical indices of broiler chickens fed raw sickle pod (Senna obtusifolia) seed meal
}

\author{
C. Augustine ${ }^{1 *}$, I.D. Kwari ${ }^{2}$, J.U. Igwebuike 2 , S.B. Adamu² \\ 'Department of Animal Production, Faculty of Agriculture, Adamawa State University, Mubi, Adamawa State, Nigeria \\ ${ }^{2}$ Department of Animal Science, Faculty of Agriculture, University of Maiduguri, Borno State, Nigeria
}

(Manuscript received 12 April 2017; accepted for publication 20 June 2017)

\begin{abstract}
A feeding trial was conducted for sixty three (63) days (9 weeks) to evaluate the effects of feeding raw Senna obtusifolia seed meal (RSOSM) on haematological indices and serum biochemical parameters of broiler chickens. Six experimental diets were compounded for both the starter (23\% crude protein - CP) and finisher (20\% CP) phases of growth. The diets were formulated to contain 0, 5, 10, 15, 20 and 25\% level of raw Senna obtusifolia seed meal replacing roasted soya bean weight for weight in $T_{1}, T_{2}, T_{3}, T_{4}, T_{5}$ and $T_{6}$ respectively. The $0 \%$ replacement level (T1) served as the control diet. The broiler chickens were managed on deep litter pens of 30 birds $/ 2.22 \mathrm{~m}^{2}$, weighed and randomly allotted to the six (6) dietary treatments in a randomized complete block design (RCBD). Each treatment group consisted of thirty (30) broiler chicks replicated three times with ten (10) broiler chicks per replicate. Blood samples were collected from the wing vein at the end of the experiment using standard procedure and were analysed for haematological and biochemical profile. The outcome of this study revealed that the haematological indices were not significantly ( $P>0.05)$ affected by the dietary treatments. However, the blood chemistry was significantly $(P<0.05)$ affected by the experimental diets. The total protein, albumin, globulin, and some electrolytes components were observed to be significantly $(P<0.05)$ depressed as the level of RSOSM increased in the experimental diets. For instance, total protein was observed to reduce from $6.24 \mathrm{~g} / \mathrm{dl}$ in $T 1$ to $3.6 \mathrm{~g} / \mathrm{dl}$ in T6. Electrolyte constituents such as calcium were similarly observed to reduce from $6.01 \mathrm{mmol} / \mathrm{lin} \mathrm{T} 1 \mathrm{to} 1.15 \mathrm{mmol} / \mathrm{l}$ in T6. The serum enzymes and bilirubin were elevated as the level of RSOSM increases in the experimental diets. Aspartate amino transferase (AST) for instance increased from 8.27U/I in T1 to $23.18 \mathrm{U} / \mathrm{I}$ in T6. It can be concluded that incorporation of RSOSM beyond $5 \%$ in the diets of broiler chickens has adverse effects on blood parameters especially the biochemical parameters.
\end{abstract}

Keywords: raw Senna obtusifolia, broiler blood constituents, toxicity testing

\section{Introduction}

The feed crises facing the Nigerian livestock industry can be minimized by harnessing the nutritional potential of wild legume seeds that are predominant in Nigeria (Augustine et al., 2016). Feed which has always been a major limiting factor in the growth of the Nigerian poultry industry accounts for over $70 \%$ total cost of producing poultry intensively (Ukachukwu and Osuagwu, 2006). The use of little known non-conventional feed resources have been encouraged by several workers (Madubuike and Ogbonnaya 2003; Okereke et al., 2006; Augustine, 2016). These feed resources are underu-terlized, less popular, cheap and can be easily sourced (Tuleun et al., 2011). One of such under-utilized legume seed in Nigeria is Senna obtusifolia seeds. Senna obtusifolia is a pantropical weed that belongs to the family Leguminosae caesapinioideae. It is an erect bushy annual shrub that grows up to $90 \mathrm{~cm}$ tall and propagates through seed. The leaves are obovate and the flowers are yellow in colour, 2-3 cm across and borne on pedicels that are 1.5-3.5 cm long (Akobundun and Agyakwa, 1998). The chemical composition of the seeds as revealed by Ingweye et al. (2010) and Ismaila et al. (2011) indicated that they have good nutritional properties (29.54 and $18.46 \%$ crude protein) but also contain antinutritional factors (tannins $388.50 \mathrm{mg} / 100 \mathrm{~g}$, phytates 240.50 $\mathrm{mg} / 100 \mathrm{~g}$ and oxalate $83.25 \mathrm{mg} / 100 \mathrm{~g}$ ) which may adversely affect blood constituents and general performance of chickens. Values for hemaetological and serum chemistry can be useful tool for interpreting toxicological and safety studies Mary et al. (2008). At the moment, base-line information concerning the effect of raw Senna obtusifolia seed meal on haematological and serum biochemical parameters of broiler chickens is very scanty, therefore more studies are needed to bridge such information gap.

\section{Material and methods}

\section{Study area}

The study was conducted at the Poultry Unit of the Department of Animal Production Livestock Teaching and Research Farm, Adamawa State University, Mubi. The area is located between latitudes $9^{\circ} 30^{\prime}$ and $11^{\circ}$ North of the equator and longitudes $13^{\circ}$ and $13^{\circ} 45^{\prime}$ East of the Greenwich meridian. The temperature regime in Mubi region is warm to hot throughout the year however, there is usually a slight cold period between November and February. There is a gradual increase in temperature from January to April. The minimum and maximum temperatures of the area are $18.1^{\circ} \mathrm{C}$ and $32.8^{\circ} \mathrm{C}$ and the mean annual rainfall ranges from $900-1050 \mathrm{~mm}$ (Adebayo, 2004).

\section{Experimental diets}

Six experimental diets for both the starter $(23 \% \mathrm{CP})$ and finisher $(20 \% \mathrm{CP})$ phases were formulated to contain $0,5,10,15,20$ and $25 \%$ of raw Senna obtusifolia seed meal designated $T_{1}, T_{2}, T_{3}, T_{4}, T_{5}$ and $T_{6}$ respectively. The raw Senna obtusifolia seed meal replaced soybean meal weight for weight in the diets. The $0 \%$ replacement

*e-mail: audaggai@gmail.com 
Table 1: Ingredient composition and calculated analysis of the experimental broiler starter diets

\begin{tabular}{|c|c|c|c|c|c|c|}
\hline \multirow{2}{*}{ Ingredient } & \multicolumn{6}{|c|}{ Level of inclusion of RSOSM } \\
\hline & $\mathrm{T} 1(0 \%)$ & $\mathrm{T} 2(5 \%)$ & T3(10\%) & T4(15\%) & T5(20\%) & T6( 25\%) \\
\hline Maize & 50.00 & 50.00 & 50.00 & 50.00 & 50.00 & 50.00 \\
\hline Roasted soya bean & 27.00 & 22.00 & 17.00 & 12.00 & 7.00 & 2.00 \\
\hline Groundnut cake & 10.00 & 10.00 & 10.00 & 10.00 & 10.00 & 10.00 \\
\hline RSOSM & 0.00 & 5.00 & 10.00 & 15.00 & 20.00 & 25.00 \\
\hline Fish meal & 5.00 & 5.00 & 5.00 & 5.00 & 5.00 & 5.00 \\
\hline Maize offal & 4.00 & 4.00 & 4.00 & 4.00 & 4.00 & 4.00 \\
\hline Salt (NaCl) & 0.30 & 0.30 & 0.30 & 0.30 & 0.30 & 0.30 \\
\hline Bone meal & 3.00 & 3.00 & 3.00 & 3.00 & 3.00 & 3.00 \\
\hline Methionine & 0.30 & 0.30 & 0.30 & 0.30 & 0.30 & 0.30 \\
\hline Lysine & 0.15 & 0.15 & 0.15 & 0.15 & 0.15 & 0.15 \\
\hline Premix* & 0.25 & 0.25 & 0.25 & 0.25 & 0.25 & 0.25 \\
\hline Total & 100.00 & 100.00 & 100.00 & 100.00 & 100.00 & 100.00 \\
\hline \multicolumn{7}{|l|}{ Calculated analysis } \\
\hline ME energy (MJ/kg) & 12.10 & 11.96 & 11.81 & 11.67 & 11.52 & 11.37 \\
\hline Crude protein (\%) & 23.47 & 23.07 & 22.67 & 22.55 & 21.20 & 20.45 \\
\hline Crude fibre (\%) & 3.09 & 3.87 & 3.92 & 3.99 & 4.11 & 4.33 \\
\hline Methionine (\%) & 0.72 & 0.72 & 0.77 & 0.79 & 0.82 & 0.87 \\
\hline Lysine (\%) & 1.24 & 1.25 & 1.26 & 1.27 & 1.28 & 1.29 \\
\hline Calcium (\%) & 1.69 & 1.70 & 1.72 & 1.73 & 1.74 & 1.76 \\
\hline Phosphorus (\%) & 0.75 & 0.72 & 0.70 & 0.68 & 0.65 & 0.63 \\
\hline
\end{tabular}

*2.5kg Vitamin-Mineral Premix (Animal Care) supplies the following: Vitamin 12,000,000 vit. $D_{3} 3000,000$, vit. E 30,000 mg, vit. $K_{3} 2,500 \mathrm{mg}$, folic acid 1,000 mg, niacin 40,000, folic acid, 1,000 mg, calpan, 10,000 mg vit. $B_{2} 5000$ mg, vit. $B_{12} 20$ mg, vit. $B_{1} 2,000 \mathrm{mg}$, vit. $B_{6} 3,500 \mathrm{mg}$, biotin $80 \mathrm{mg}$ and antioxidant $125,000 \mathrm{mg}$, cobalt $250 \mathrm{mg}$, selenium $250 \mathrm{mg}$, iodine 1,200 $\mathrm{mg}$, iron $40,000 \mathrm{mg}$, manganese 70,000mg, copper 8,000 mg, zinc 60,000 mg, chloride 200,000 mg. Metabolizable energy (ME) calculated according to the formula of Pauzenga (1985) ME $=37 \times \%$ CP $+81 \times \% \mathrm{EE}+35.5 \times \%$ NFE and RSOSM = Raw Senna obtusifolia seed meal

Table 2: Ingredient composition and calculated analysis of the experimental broiler finisher diets

\begin{tabular}{|c|c|c|c|c|c|c|}
\hline \multirow{2}{*}{ Ingredient } & \multicolumn{6}{|c|}{ Level of inclusion of RSOSM } \\
\hline & $\mathrm{T} 1(0 \%)$ & $\mathrm{T} 2(5 \%)$ & T3(10\%) & $\mathrm{T} 4(15 \%)$ & $\mathrm{T} 5(20 \%)$ & T6( 25\%) \\
\hline Maize & 54.00 & 54.00 & 54.00 & 54.00 & 54.00 & 54.00 \\
\hline Roasted soya bean & 27.00 & 22.00 & 17.00 & 12.00 & 7.00 & 2.00 \\
\hline Groundnut cake & 7.00 & 7.00 & 7.00 & 7.00 & 7.00 & 7.00 \\
\hline Fish meal & 3.00 & 3.00 & 3.00 & 3.00 & 3.00 & 3.00 \\
\hline Maize offal & 5.00 & 5.00 & 5.00 & 5.00 & 5.00 & 5.00 \\
\hline RSOSM & 0.00 & 5.00 & 10.00 & 15.00 & 20.00 & 25.00 \\
\hline Salt (NaCl) & 0.30 & 0.30 & 0.30 & 0.30 & 0.30 & 0.30 \\
\hline Bone meal & 3.00 & 3.00 & 3.00 & 3.00 & 3.00 & 3.00 \\
\hline Methionine & 0.30 & 0.30 & 0.30 & 0.30 & 0.30 & 0.30 \\
\hline Lysine & 0.15 & 0.15 & 0.15 & 0.15 & 0.15 & 0.15 \\
\hline Premix* & 0.25 & 0.25 & 0.25 & 0.25 & 0.25 & 0.25 \\
\hline Total & 100.00 & 100.00 & 100.00 & 100.00 & 100.00 & 100.00 \\
\hline \multicolumn{7}{|l|}{ Calculated analysis } \\
\hline ME energy (MJ/kg) & 12.33 & 12.13 & 12.05 & 11.95 & 11.80 & 11.62 \\
\hline Crude protein $(\%)$ & 21.01 & 20.61 & 20.21 & 19.85 & 19.76 & 19.45 \\
\hline Crude fibre $(\%)$ & 3.69 & 4.11 & 4.23 & 4.38 & 4.49 & 4.51 \\
\hline Methionine (\%) & 0.70 & 0.72 & 0.72 & 0.73 & 0.75 & 0.77 \\
\hline Lysine $(\%)$ & 1.04 & 1.13 & 1.38 & 1.41 & 1.44 & 1.42 \\
\hline Calcium (\%) & 1.14 & 1.14 & 1.16 & 1.18 & 1.21 & 1.23 \\
\hline Phosphorus (\%) & 0.68 & 0.61 & 0.59 & 0.51 & 0.49 & 0.45 \\
\hline
\end{tabular}

*2.5 kg Vitamin-Mineral Premix (Animal Care) supply the following: Vitamin 12,000,000 vit. $D_{3} 3000,000$, vit. E 30,000 mg vit. $K_{3} 2,500 \mathrm{mg}$, folic acid $1,000 \mathrm{mg}$, niacin 40,000 , folic acid, $1,000 \mathrm{mg}$, calpan, 10,000 mg vit. B2 $5000 \mathrm{mg}$ vit. B $20 \mathrm{mg}$, vit. $B_{1} 2,000 \mathrm{mg}$, vit. $B_{6} 3,500 \mathrm{mg}$, biotin $80 \mathrm{mg}$ and antioxidant $125,000 \mathrm{mg}$, cobalt $250 \mathrm{mg}$, selenium $250 \mathrm{mg}$, iodine 1,200 $\mathrm{mg}$, iron $40,000 \mathrm{mg}$, manganese $70,000 \mathrm{mg}$, copper $8,000 \mathrm{mg}$ zinc $60,000 \mathrm{mg}$ chloride 200,000 mg. Metabolizable energy (ME) calculated according to the formula of Pauzenga (1985) ME $=37 \times \% \mathrm{CP}+81 \times \% \mathrm{EE}+35.5 \times \% \mathrm{NFE}$ and RSOSM $=$ Raw Senna obtusifolia seed meal 
level (T1) served as the control diet. The ingredient and calculated chemical composition of the experimental diets are presented in Tables 1 and 2.

\section{Experimental chickens and their management}

One hundred and eighty broiler (180) chicks were used for the experiment which lasted for sixty three (63) days. The broiler chickens were managed on deep litter pens of 30 birds $/ 2.22 \mathrm{~m}^{2}$ and were vaccinated against Gumboro ( 2 and 4 weeks of age) and Newcastle disease ( 3 and 5 weeks of age). The experimental broiler starter diet was fed ad-libitum to the chicks for forty two (42) days while the broiler finisher diet was fed for the remaining twenty one (21) days, respectively. Clean drinking water was similarly supplied ad-libitum throughout the period of the experiment.

\section{Experimental design}

The chicks were individually weighed and randomly allotted to the six (6) dietary treatments in a randomized completely block design (RCBD) with pen location serving as the blocking factor. Each treatment group consisted of thirty (30) birds replicated three times with ten (10) birds per replicate.

\section{Collection of blood sample and analysis}

At the end of the experiment, three (3) birds were randomly selected from each replicate pen for haematological and biochemical parameters. About $7 \mathrm{ml}$ of blood samples each for haematological and biochemical analysis was collected from the wing vein using a sterile disposable needle and syringe. The blood samples for haematological assay were collected in ethylene diamine tetra acetic acid (EDTA) treated tubes. Blood samples for biochemical analysis, were collected into EDTA-free test tubes and allowed to clot for serum separation. Serum was separated from the plasma by centrifugation of the blood at $4000 \mathrm{rpm}$ for 15 minutes and thereafter quickly taken to the laboratory for analyses. The haematology and blood chemistry analyses were carried out according to the procedure of Ochei and Kolhatkar (2000).

Erythrocytic indices (mean corpuscular haemoglobin concentration - MCHC), mean corpuscular haemoglobin $(\mathrm{MCH})$ and mean corpuscular volume - MCV) were calculated using the formulae of Jain (1986) as follows:

$$
\operatorname{MCHC}(\%)=\frac{\mathrm{Hb}(\mathrm{g} / \mathrm{dl}) \times 100}{\operatorname{PCV}(\%)}
$$

$$
\begin{aligned}
& \operatorname{MCH}(f l)=\frac{H b(g / d l) \times 10}{\operatorname{RBC}\left(\times 10^{6} U L\right)} \\
& \operatorname{MCV}(p g)=\frac{\operatorname{PCV~}(\%) \times 10}{\operatorname{RBC}(\text { million })}
\end{aligned}
$$

\section{Statistical analysis}

Data obtained were subjected to analysis of variance (ANOVA) of the randomized complete block design (RCBD) using Statistix 9.0 (Statistix, 2003). Least Significant Difference (LSD) was used to separate the treatment means where significant differences occur. Significant difference was considered at $95 \%$ level of confidence.

\section{Results and discussion}

The haematological indices of broiler chickens fed raw Senna obtusifolia seed meal are presented in Table 3. Inclusion levels of RSOSM up to $25 \%$ did not cause significant $(P>0.05)$ change in the haematological parameters. However, the packed cell volume (PCV), white blood cells (WBC) count, haemoglobin ( $\mathrm{Hb})$, mean corpuscular volume (MCV), mean corpuscular haemoglobin $\mathrm{MCH}$ ) and mean corpuscular haemoglobin concentration (MCHC) obtained in this study were lower than the normal ranges of $35.9-$ $41.0 \%, 4.07-4.32 \times 10^{-3} / \mathrm{ml}, 81.6-89.10 \mathrm{fl}, 27.20-28.90 \mathrm{pg}$, and $32.41-33.37 \%$, respectively reported by Wikivet (2013). This could be due to the effects of the anti-nutritional factors which might have affected the haematological indices of the broiler chickens.

However, the red blood cell falls within the normal range 4.21 $4.84 \times 10^{6}$ reported by Wikivet (2013) for broiler chickens of similar ages. This an indication of better capacity to carry oxygen in the body of the chickens (Ochei and Kolhatkar, 2000; Phillips and Best, 2004).

Haematological and serum biochemical parameters are good indicators of the physiological and health status of animal and its changes are of value in assessing the response of animals to various physiological situations (Khan and Zafar, 2005). This corroborates the report of Obun et al. (2009) who revealed the negative effects of anti-nutritional factors present in raw Afzelia africana seed meal on haematological parameters of broiler starter chicks. However, the haemoglobin values recorded in this study were within the range of 5 to $7.67 \mathrm{~g} / \mathrm{dl}$ reported by Obun et al. (2009) for broiler chickens of

\begin{tabular}{|c|c|c|c|c|c|c|c|}
\hline \multirow{2}{*}{ Parameters } & \multicolumn{7}{|c|}{ Level of inclusion of RSOSM } \\
\hline & $\mathrm{T} 1(0 \%)$ & $\mathrm{T} 2(5 \%)$ & T3(10\%) & $\mathrm{T} 4(15 \%)$ & $\mathrm{T} 5(20 \%)$ & T6( 25\%) & SEM \\
\hline Packed cell volume (\%) & 18.67 & 19.33 & 19.67 & 19.17 & 18.67 & 19.67 & $0.69^{\mathrm{NS}}$ \\
\hline Haemoglobin (g/dl) & 6.08 & 6.03 & 6.30 & 6.26 & 5.70 & 6.13 & $0.85^{\mathrm{NS}}$ \\
\hline $\mathrm{RBC}\left(\mathrm{x} 10^{6} / \mathrm{ml}\right)$ & 4.77 & 4.61 & 4.57 & 4.47 & 4.46 & 4.50 & $0.17^{\mathrm{NS}}$ \\
\hline WBC $\left(x 10^{3} / \mathrm{ml}\right)$ & 1.57 & 1.97 & 1.33 & 1.67 & 1.40 & 1.60 & $0.23^{\mathrm{NS}}$ \\
\hline $\operatorname{MCV}(\mathrm{fl})$ & 39.14 & 41.93 & 43.04 & 42.88 & 41.86 & 43.71 & $1.51^{\mathrm{Ns}}$ \\
\hline $\mathrm{MCH}(\mathrm{pg})$ & 12.74 & 13.08 & 13.78 & 13.93 & 13.98 & 13.62 & $1.99^{\mathrm{NS}}$ \\
\hline $\mathrm{MCHC}(\%)$ & 32.57 & 31.19 & 32.02 & 32.65 & 30.53 & 31.16 & $0.36^{\mathrm{NS}}$ \\
\hline
\end{tabular}
similar age fed raw and toasted Afzelia africana seed meal, an

Table 3: Haematological indices of broiler chickens fed raw Senna obtusifolia seed meal

NS = Not significant; SEM $=$ Standard error of the means, RBC $=$ Red blood cells; $W B C=$ Red blood cells MCV $=$ Mean Corpuscular Volume, $\mathrm{MCH}=$ Mean corpuscular haemoglobin, $\mathrm{MCV}=$ mean corpuscular volume, $\mathrm{MCH}=$ mean corpuscular haemoglobin, $\mathrm{MCHC}=$ mean corpuscular haemoglobin concentration, RSOSM = Raw Senna obtusifolia seed meal 
alternative legume seed.

The results of the biochemical indices of broiler chickens fed graded levels of RSOSM are presented in Table 4. The results revealed that total protein, albumin and globulin were significantly $(P<0.05)$ influenced by the dietary treatments. The values for these parameters decreased as the level of RSOSM increased in the experimental diets. The linear decline for these parameters are indications of poor protein intake and utilization by the chickens. This is related to increase in the concentration of the anti-nutritional factors consequently affecting protein utilization. This finding is consistent with the report of Emiola et al. (2013) who attributed a decrease in serum protein of broiler chickens fed dehulled mucuna seed meal to the inhibition of protein utilization by the anti-nutritional factors present in the seed meal. Ekpenyong et al. (2012) further stressed that the liver synthesizes protein and low levels could reflect impaired synthesis. Abnormal serum albumin usually indicates an alteration of normal systemic protein utilization (Apata, 1990). However, the total protein of broiler chickens fed 0 and $5 \%$ RSOSM were within the normal range $4.63-4.81 \mathrm{~g} / \mathrm{dl}$ reported by Wikivet (2013) for broiler chickens of similar age while broiler chickens in the other treatment groups recorded total protein levels that are slightly lower than the normal range. This may be attributed to the adverse effects of anti-nutritional factors such as tannins, saponins, oxalates and phytates. This is in agreement with the findings of Akinmutimi and Onen (2008) who similarly fed broiler chickens with yam peel meal and recorded lower values of total protein, albumin and globulin. Tannins and total free phenolics were reported to decrease digestibility of proteins, carbohydrate and the availability of vitamins and minerals (Liener, 1994). These antinutritional factors also decreased the activities of digestive enzymes and may cause damage to the mucosa of digestive tract and reduced the absorption of nutrients (Doss et al., 2011) which are needed for the synthesis of blood components.

Blood uric acid of the chickens fed the different experimental diets were significantly $(P<0.05)$ affected by the diets. The broiler chickens fed 0 and $5 \%$ RSOSM recorded similar values which were significantly $(\mathrm{P}<0.05)$ lower than the values for broiler chickens fed 10, 15, 20 and 25\% RSOSM. The significant increase in uric acid levels of the chickens fed higher levels of the raw seed meal was attributed to the effect of high concentration of anti-nutritional factors present in the seed meal which consequently affected the quality of protein and utilization. This was buttressed by Abiola (2001) who observed that high uric acid value is an indication of poor protein quality. Akinmutimi and Onen (2008) also reported similar adverse effect of yam peel meal on broiler chickens and implicated antinutritional factors as the cause of such effect.

Cholesterol values were significantly $(P<0.05)$ lower in broiler chickens fed 15, 20 and 25\% of RSOSM. Wardah et al. (2012) in a similar study fed broiler chickens with $5 \%$ powdered leaves of Phyllanthus buxifolus and reported significantly $(\mathrm{P}<0.05)$ lower cholesterol values compared to group of chickens fed the positive control diet. The authors attributed the reduction of the cholesterol to the effects of phytochemicals present in the leaf meal which supported the findings of this study. Ueda (2001) and Dong et al. (2007) explained that saponins play a role in lowering cholesterol because, saponins can form insoluble complexes bond with cholesterol from food in the gut and inhibit its absorption in the intestine. Saponins and pectins can also inhibit the absorption of fat and cholesterol from food so that these substances cannot be absorbed.

The level of creatinine as affected by the dietary treatments showed significant $(P<0.05)$ differences among the treatment

Table 4. Biochemical indices of broiler chickens fed graded levels of raw Senna obtusifolia seed meal

\begin{tabular}{|c|c|c|c|c|c|c|c|}
\hline \multirow{2}{*}{ Parameters } & \multicolumn{7}{|c|}{ Level of inclusion of RSOSM } \\
\hline & $\mathrm{T} 1(0 \%)$ & $\mathrm{T} 2(5 \%)$ & T3(10\%) & $\mathrm{T} 4(15 \%)$ & $\mathrm{T} 5(20 \%)$ & T6 $(25 \%)$ & SEM \\
\hline Total protein (g/dl) & $6.24^{\mathrm{a}}$ & $4.51^{b}$ & $3.44^{\circ}$ & $3.85^{\circ}$ & $3.84^{\circ}$ & $3.61^{\circ}$ & $1.13^{*}$ \\
\hline Albumin (g/dl) & $3.21^{\mathrm{a}}$ & $2.34^{\mathrm{b}}$ & $2.34^{c}$ & $2.22^{\mathrm{c}}$ & $2.20^{\mathrm{c}}$ & $1.98^{\mathrm{d}}$ & $0.35^{\star}$ \\
\hline Globulin (g/dl) & $3.03^{\mathrm{a}}$ & $2.17^{\mathrm{b}}$ & $1.10^{b}$ & $1.63^{\mathrm{c}}$ & $1.64^{\mathrm{c}}$ & $1.63^{c}$ & $0.36^{*}$ \\
\hline Uric acid (mmol/l) & $21.00^{c}$ & $21.09^{c}$ & $31.23^{b}$ & $29.83^{b}$ & $27.80^{\mathrm{b}}$ & $40.07^{a}$ & $1.97^{*}$ \\
\hline Cholesterol (mg/dl) & $90.78^{\mathrm{a}}$ & $50.51^{b}$ & $50.17^{b}$ & $20.28^{c}$ & $20.82^{c}$ & $20.58^{\mathrm{bc}}$ & $0.77^{*}$ \\
\hline Creatinine $(\mathrm{mmol} / \mathrm{l})$ & $52.53^{\mathrm{e}}$ & $72.33^{c}$ & $64.57^{\mathrm{d}}$ & $107.77^{\mathrm{a}}$ & $97.67^{b}$ & $96.53^{b}$ & $23.47^{*}$ \\
\hline Calcuim (mmol/l) & $6.01^{\mathrm{a}}$ & $3.15^{b}$ & $3.01^{\mathrm{b}}$ & $2.11^{\mathrm{c}}$ & $1.67^{\mathrm{d}}$ & $1.51^{\mathrm{d}}$ & $0.35^{*}$ \\
\hline Phosphorus (mmol/l) & 2.71 & 2.31 & $2.3^{0}$ & $2.1^{1}$ & 2.08 & 2.31 & $0.96^{\mathrm{NS}}$ \\
\hline Potassium (mmol/l) & $3.97^{b}$ & $3.07^{b}$ & $4.37^{\mathrm{a}}$ & $3.90^{\mathrm{b}}$ & $2.20^{c}$ & $2.87^{\mathrm{bc}}$ & $0.61^{*}$ \\
\hline Sodium (mmol/l) & $100.34^{a}$ & $96.17^{b}$ & $65.84 b^{c}$ & $60.14^{c}$ & $58.33^{c}$ & $60.08^{c}$ & $3.07^{*}$ \\
\hline Chloride $\mathrm{Cl}^{-}(\mathrm{mmol} / \mathrm{l})$ & $101.63^{\mathrm{a}}$ & $97.50^{b}$ & $64.00^{\circ}$ & $65.33^{\mathrm{c}}$ & $62.77^{\mathrm{d}}$ & $60.33^{d}$ & $2.59^{*}$ \\
\hline Bicarbonate $(\mathrm{mmol} / \mathrm{l})$ & $28.6^{7}$ & 27.67 & 28.67 & $29.3^{3}$ & $29.6^{7}$ & 27.67 & $3.76^{\mathrm{NS}}$ \\
\hline Alkaline phosphatase (U/l) & $48.10^{\mathrm{a}}$ & $27.11^{b}$ & $25.66^{b}$ & $25.03^{b}$ & $25.17^{b}$ & $23.18^{b}$ & $4.6^{*}$ \\
\hline AST (U/I) & $8.27^{d}$ & $11.90^{\circ}$ & $19.73^{b}$ & $18.68^{b}$ & $17.68^{b}$ & $31.60^{\mathrm{a}}$ & $4.71^{*}$ \\
\hline $\mathrm{ALT}(\mathrm{U} / \mathrm{l})$ & $5.45^{\mathrm{b}}$ & $5.90^{\mathrm{b}}$ & $6.70^{\mathrm{a}}$ & $6.48^{\mathrm{a}}$ & $7.20^{\mathrm{a}}$ & $6.60^{\mathrm{a}}$ & $2.18^{*}$ \\
\hline Total billirubin $(\mathrm{mmo} / \mathrm{l})$ & $6.17^{d}$ & $13.00^{b}$ & $10.10^{c}$ & $13.13^{b}$ & $11.10^{c}$ & $17.23^{\mathrm{a}}$ & $0.76^{*}$ \\
\hline $\mathrm{CB}(\mathrm{mmol} / \mathrm{l})$ & $2.46^{d}$ & $5.55^{\circ}$ & $8.88^{b}$ & $7.17^{b}$ & $6.15^{\circ}$ & $12.28^{\mathrm{a}}$ & $0.42^{*}$ \\
\hline
\end{tabular}

NS = Not significant, SEM $=$ Standard error of the means, $\mathrm{RBC}=$ Red blood cells, WBC $=$ Red blood cells MCV $=$ Mean Corpuscular Volume, $\mathrm{MCH}=$ Mean corpuscular haemoglobin, $\mathrm{MCV}=$ mean corpuscular volume, $\mathrm{MCH}=$ mean corpuscular haemoglobin, $\mathrm{MCHC}=$ mean corpuscular haemoglobin concentration, RSOSM = Raw Senna obtusifolia seed meal 
means. Broiler chickens fed the positive control diet (0\% RSOSM) recorded the lowest value of $52.53 \mathrm{mmol} / /$ while the other groups of broiler chickens fed 15, 20 and 25\% RSOSM showed higher values. High creatinine levels indicates abnormality of the kidney and therefore broiler chickens fed 15,20 and 25\% levels were suspected to have kidney abnormality. This adverse effect may be due to the effects of high concentration of anti-nutritional factors in the diets containing 15-20\% levels of RSOSM. Ojediran et al. (2012) pointed out that creatinine is a waste product of protein metabolism that is excreted via the kidney which is the most sensitive biomarkers employed in the diagnosis of renal damage. Therefore, the significant increase $(P<0.05)$ in creatinine levels recorded in this study may be an indication that the kidneys of the chickens fed higher levels of RSOSM were adversely affected by the antinutritional factors present in the diets. The creatinine value which is within the range of $52.53-107.77 \mathrm{mmol} / \mathrm{l}$ is however, higher than the value of $44 \mathrm{mmol} / /$ reported by Isidahomen et al. (2011) for broiler chickens of similar age.

The electrolyte constituents of broiler chickens fed graded levels of RSOSM were significantly $(P<0.05)$ influenced by the experimental diets. The levels of some of the electrolyte constituents were observed to decline as the levels of RSOSM increased in the experimental diets. This observed trend may be due to increase in the concentration of anti-nutritional factors as the levels of RSOSM increased in the diets. Dan (2005) reported that phytates can chelate divalent metals or even block the absorption of essential minerals in the intestinal tract consequently affecting their availability in the body of animals. Ekeanyanwu et al. (2010) further pointed out that oxalate can adversely affect calcium utilization by removing it from the blood in form of calcium oxalates consequently resulting to renal damage. Dyer et al. (2000) in their study reported that electrolyte constituents are essential tools in assessing the functional capacity of the kidney. The calcium levels which ranged from 1.51 to $6.01 \mathrm{mg} / \mathrm{dl}$ in diets T1 to $\mathrm{T} 6$ are lower than the value of $9.34 \mathrm{mg} / \mathrm{dl}$ reported by Isidahomen et al. (2011). The phosphorus level is also lower than the phosphorus value of $4.14 \mathrm{mg} / \mathrm{dl}$ reported by same authors. The bicarbonate value recorded in this study is lower than the value of $30 \mathrm{mmol} / \mathrm{l}$ reported by Borges et al. (2003). The levels of the hepatic enzymes such as aspartate amino transferase (AST) and alanine amino transferase (ALT) were significantly elevated in broiler chickens fed $10,15,20$ and $25 \%$ levels of RSOSM with $25 \%$ levels recording the highest value. The general pattern showed that the levels of the enzymes increased with increasing levels of the RSOSM. This elevation of these serum enzymes, is linked to increase in the concentration of the toxic components of the seed as the levels of the seed meal increases. These liver enzymes are usually used as surrogate markers for hepatic injury (Dobbs, 2003; Liz, 2003; Svetlovet, 2003). The result of this study is in agreement with that of Emiola et al. (2013) who reported that increased activities of hepatic transaminase is an indication of increased catabolism of amino acids and liver damage. The ALT obtained in this study is higher than the normal value $(10.20 \mu / /)$ reported by Bahman et al. (2014).

The levels of total bilirubin and conjugate bilirubin recorded in this study, indicated significantly $(P<0.05)$ linear increase as the levels of RSOSM increased in the experimental diets. The increase in levels of the anti-nutritional factors as the level of the raw seed meal ascends might be the major cause of this effect and may adversely affect the physiological functions of the liver. Howard (2009) reported that elevated bilirubin levels in the blood are pointer towards liver injury. The lower levels of both total and conjugate bilirubin observed in the positive control group may be due to the absence of RSOSM in the diets.

\section{Conclusion}

Haematological results showed that packed cell volume (PCV), white blood cells (WBC) count, haemoglobin $(\mathrm{Hb})$, mean corpuscular volume (MCV), mean corpuscular haemoglobin $\mathrm{MCH}$ ) and mean corpuscular haemoglobin concentration $(\mathrm{MCHC})$ of the broiler chickens fed the experimental diets were not significantly different among the treatment groups. However, haematological values obtained were slightly lower than the normal range for broiler chickens of similar age. The biochemical indices of the broiler chickens revealed a significant variation among the treatment groups. Total protein, albumin and globulin were observed to decrease with progressive increase in the level of raw Senna obtusifolia seed meal (RSOSM). Similarly, the serum electrolyte components (calcium, phosphorus, sodium, chloride and bicarbonate) indicated a reducing trend as the concentration of RSOSM increases in the experimental diets. The serum enzymes (aspartate amino transferase and alanine amino transferase) were observed to be elevated as the concentration of RSOSM increases in the diets. The bilirubin levels were also observed to be more elevated at $25 \%$ inclusion level of RSOSM. It can be concluded that incorporation of RSOSM beyond $5 \%$ in the diets of broiler chickens has adverse effects on blood parameters especially the biochemical parameters.

\section{Reference}

Abiola SS, 2001. Haematological indices and serum metabolites of cockerel fed hatchery waste meal diets. Tropical Veterinian, 18, 7984.

Adebayo AA, 2004. Mubi region a geograhical sysnthesis paraclete. Publishers Yola, Nigeria, p. 133

Akinmutimi $\mathrm{AH}$ and Onen GE, 2008. The response of broiler finisher birds fed graded levels of yam peel meal in place of maizebased diets. International Journal of Poultry Science, 7, 474-479.

Akobundu 10 and Agyakwa CW, 1998. A Handbook of West African Weeds $2^{\text {nd }}$ ed. Published by INTEC printers, Ibadan, p. 306.

Apata DF, 1990. Biochemical, nutritional and toxicogical assessment of some tropical legume seeds. Thesis for MSc, submitted to Faculty of Agriculture, University of Ibadan, Ibadan, Nigeria.

Augustine C, Abdulrahaman BS, Sudi IY, Zira SP, Kwari ID, Tarimbuka LI, Midiga R and Nyalas BP, 2016. Evaluation of nutrient and anti-nutrient components of coffee senna (Senna occidentalis) seed meal in Mubi. Adamawa State University Journal of Scientific Research, 4, 66-71.

Augustine C, 2016. Evaluation of sickle pod (Senna obtusifolia) seed meal as source of protein for domestic chickens. Thesis for $\mathrm{PhD}$, Department of Animal Science, University of Maiduguri, Borno State, Nigeria.

Bahman A, Alireza T and Siamak A, 2014. Biochemical profile of chickens: Comparative study on blood profile of indigenous and Ross 308-Broiler breeders, p. 197.

Borges SA, Fischerda Silva VA, Ariki Jl, Hooge DM and Cummings KR, 2003. Dietary electrolyte balance for broiler chickens exposed to themoneutral or heat-stressed environment. Poultry Science, 82, 428-435.

Dan I, 2005. Health-fresh controversy over safety of soybean. The Punch News Paper, 26, 46.

Dobbs NA, Twelves CJ, Gresory WJ, Cruckshank C, Richard MA 
and Reubens RD, 2003. Epirubicin in patient with liver dysfunction development and evaluation of novel dose modification scheme. European Journal of Cancer, 39, 580-586.

Dong XF, Gao WW, Tong JM, Jia HQ, Sa RN and Zhang Q, 2007. Effect of polysavone (Alfalfa extract) on abdominal fat deposition and immunity in broiler chickens. Poultry Science, 86, 1955-1959.

Doss A, Pugalenthgi M, Vadivel VG, Subashini G and Anitha Subash R, 2011. Effects of processing technique on the nutritional composition and anti-nutritients of under-utilized food legume. International Food Research, 18, 965-970.

Dyer A, Morgan S, Wells P and Williams EC, 2000. The use of zeolites as low release antihelminthic carriers. Journal of Helminthology, 74, 137-141.

Ekeanyanwu RC, Njoku 0 and Ononogbu IC, 2010. The phytochemical composition and some biochemical effects of Nigerian tiger nut (Cypercus esculentus L). Pakistan Journal of Nutrition, 9, 709-715.

Ekpenyong CE, Akpan EE and Udo NS, 2012. Phytochemistry and toxicity studies of Telfairia occidentalis aqueous leaves extract on liver biochemical indices in Wistar rats. American Journal of Medicine and Medical Sciences, 2, 103-104.

Emiola IA, Ojediran TK and Ayaji JA, 2013. Biochemical and haematological indices of broiler chickens fed differently processed legume seed meals. International Journal of Applied Agriculture and Apiculture, 1 \& 2, 140-149.

Howard JW, 2009. Cirrhosis. In: Microsoft Encarta, DVD Raymond, W.A. Microsoft cooperation 2008.

Ingweye JN, Kalio GA, Ubua JA and Umoren EP, 2010. Nutritional evaluation of wild sickle pod (Senna obtusifolia) seeds from Obanliku, South - Eastern, Nigeria. American Journal of Food Technology, 5, 1-12.

Isidahomen CE, Ozoje MO and Njidda AA, 2011. Haematological and serum biochemical indices of local and exotic chickens in a subtropical and tropical environment. European Journal of Biological Sciences, 3, 16-21.

Ismaila YS, Denban MK, Emmanuel KM and Augustine C, 2011. Nutritional and phytochemical screening of Senna obtusifolia indigenous to Mubi. Advances in Applied Science Research, 22, 432-437.

Jain NC, 1986. Schalm's Veterinary Haematology ( $4^{\text {th }}$ edition). Lea and Febiger, Philadelphia, USA.

Khan TA and Zafar F, 2005. Haematological study in response to varying doses of estrogen in broiler chickens. International Journal of Poultry Science, 10, 751-784.

Liener IE, 1994. Implication of anti-nutritional components in soybean foods. CRC. Critical Review in Food Science and Nutrition, $34,31-67$.

Liz H, 2003. Monitoring test for people with HIV-Liver Function test. Bulletin of experimental treatment for AIDS, http:/www.aegis.com/ pubs/beta/2003/be030203html retrieved 9/6/2015.

Madubuike FN and Ogbonnaya 0, 2003. The potential use of white star apple seed (Chrysophyllum albidum) and physic nut (Jatropha curcas) as feed ingredients for rats. Journal fact. Agricultural Veterinary Medicine, 1, 97-105.

Mary LA Giknis and Charles B Clifford, 2008. Clinical laboratory parameters for Crl:WI (Han), p. 2.

Obun CO, Ayanwale BA, Yahya MS, Allison DS and Olafadehan OA, 2009. Growth and haematological status of starter broiler chicks fed diets containing Afzelia africana seed meals In: Proceedings of the $14^{\text {th }}$ Annual Conference of Animal Science Association of Nigeria (ASAN), September $14^{\text {th }}-17^{\text {th }}, 2009$, LAUTECH, Ogbomoso, Nigeria, pp. 465-467.

Ochei T and Kolhatkar A, 2000. Medical Laboratory Science Theory and Practice. Tata McGraw-Hill Publishing Company Limited, New Delhi, India, p. 1232.

Ojediran TK, Emiola IA, Ogunwemimo O and Olayeni TB, 2012. Effect of processed Jatropha curcas kernel cake on the blood profile and biochemical indices of broiler. In: Proceeding of the $17^{\text {th }}$ Annual Conference of Animal Science Association of Nigeria (ASAN) $9^{\text {th }}-13^{\text {th }}$ September, Abuja, pp. 509-512.

Okereke CO Ukachukwu SN and Nsar EE 2006. Potentials of cassava leaves and/or foliage in poultry In. Proceedings of the $40^{\text {th }}$ Annual Conference of the Agricultural Society of Nigeria (ASN), Abia State, Nigeria, pp. 515-617.

Pauzenga U, 1985. Feeding parent stock. Zootecnia International, pp. 22-25.

Phillips JE and Best MA, 2004. Liver Function Test. Gale Encyclopedia of Surgery: A guide for patients and caregivers http://www.encyclopedia.com> retrieved on $21^{\text {st }}$ May, 2016.

Statistix, 2003. Statistix for windows manual. Analytical Software. Version 8.0.

Svetlovet SL, Xiang Y, Oli MW, Foley DP, Huang G, Hayes RL, Ottens AK and Wang KW, 2006. Identification and preliminary validation of novel biomarkers of acute hepatic ischemical/ reperfusion injury using dual platform proteomic/degradomic approaches. Biomakers, 11, 355-369.

Tuleun CD, Adenkola AY and Orayaga KT, 2011. Naturally fermented mucuna seed meal based diets: effect on performance and carcass characteristics of broiler chickens. Research Journal of Poultry Science, 4, 50-55.

Ueda H, 2001. Short-term feeding response in chicks to tea saponin. Journal of Poultry Science, 86, 1955-1959.

Ukachukwu SN and Osuagwu NC, 2006. Digestibility and energy metabolism of raw mucuna coccinchinensis by growing rabbits. Journal of Sustainable Agriculture, 8, 141-144.

Wardah TS, Bimo Aksono E and Kusriningrum H, 2012. Reduction of intracellular lipids accumulation serum leptin and cholesterol levels in broilers fed diet supplemented with powder leaves of Phyllanthus buxifolius. Asian Journal of Agricultural Science, 6, 106-117.

Wikivet, 2013. Chicken haematology reference ranges. https://en. wikivet.net/indexphp?title=chickenhaematology\&oldid= 140033. Retrieved $26^{\text {th }}$, June, 2015. 
Reviews

Problems and achievements of cotton (Gossypium Hirsutum L.) weeds control

T. Barakova, G. Delchev

Achievements and problems in the weed control in grain sorghum (Sorghum Bicolor Moench.)

G. Delchev, M. Georgiev

\section{Genetics and Breeding}

Parthenogenetic responsiveness of sunflower hybrid combinations with expressed tolerance to herbicides

M. Drumeva, P. Yankov

In vitro propagation of oil-bearing rose (Rosa damascena Mill.)

V. Badzhelova

\section{Nutrition and Physiology}

Variation in the chemical composition and physical characteristics of grain from winter barley varieties

B. Dyulgerova, N. Dyulgerov, D. Dimova

Haematological and serum biochemical indices of broiler chickens fed raw sickle pod (Senna obtusifolia) seed meal

C. Augustine, I.D. Kwari, J.U. Igwebuike, S.B. Adamu

Prey size selectivity of pikeperch (Sander Lucioperca L.) fed with topmouth gudgeon (Pseudorasbora Parva Temminck \& Schlegel)

M. Gevezova-Kazakova, M. Yankova, T. Hubenova, A. Zaikov, G. Rusenov

Influence of organic nitrogen amendment, containing amino acids on the cellulase and xylanase, produced by Trichoderma spp. isolates

D. Draganova, I. Valcheva, Y. Kuzmanova, M. Naydenov

\section{Production Systems}

Justification of a method for determining the moment for switching on the level one signaling of filled grain harvester hoppers

G. Tihanov, B. Kolev, K. Trendafilov, N. Delchev, Y. Stoyanov

Mathematical approaches for assessment and classification of the European Union member states based on the average yield of vegetables for the period 1961-2014

N. Keranova 
Present status of Zymoseptoria tritici (Mycospharella graminicola /Fuckel/ Schroter) of the wheat cultures in the Republic of Macedonia

I. Karov, E. Arsov

\section{Agriculture and Environment}

Influence of basic agrotechnical activities on the productivity and yield of Triticum monococcum $\mathrm{L}$.

S. Stamatov, K. Uzundzhalieva, E. Valchinova, G. Desheva, P. Chavdarov, B. Kyosev, T. Cholakov, R.

Ruseva, N. Velcheva

Avifauna abundance and diversity in Jos wildlife park, Nigeria

B.T. Kwaga, D. lliya, A. Ali, D. Khobe

Ecological analysis of the flora in the 'Chinarite' protected area - Rodopi municipality, Bulgaria

L. Dospatliev, M. Lacheva

Product Quality and Safety

Food emulsions with amidated pectin from celery (Apium graveolens var. rapaceum D. C.) tubers Iv. Petrova, N. Petkova, M. Ognyanov, Ap. Simitchiev, M. Todorova, P. Denev

M. Tonchev, T. Atanasov, A. Todorova, Ts. Atanasova, N. Shtrankova, M. Momchilova G. Zsivanovits

\section{Short Communication}

Influence of elevated platform (wire-mesh or wooden) in the cage on domestic rabbit (Oryctolagus cuniculus) activity

S. Peeva, E. Raichev, D. Georgiev, A. Stefanov 


\section{Instruction for authors}

\section{Preparation of papers}

Papers shall be submitted at the editorial office typed on standard typing pages (A4, 30 lines per page, 62 characters per line). The editors recommend up to 15 pages for full research paper ( including abstract references, tables, figures and other appendices)

The manuscript should be structured as follows: Title, Names of authors and affiliation address, Abstract, List of keywords, Introduction, Material and methods, Results, Discussion, Conclusion, Acknowledgements (if any), References, Tables, Figures.

The title needs to be as concise and informative about the nature of research. It should be written with small letter /bold, 14/ without any abbreviations.

Names and affiliation of authors The names of the authors should be presented from the initials of first names followed by the family names. The complete address and name of the institution should be stated next. The affiliation of authors are designated by different signs. For the author who is going to be corresponding by the editorial board and readers, an E-mail address and telephone number should be presented as footnote on the first page. Corresponding author is indicated with *

Abstract should be not more than 350 words. It should be clearly stated what new findings have been made in the course of research. Abbreviations and references to authors are inadmissible in the summary. It should be understandable without having read the paper and should be in one paragraph.

Keywords: Up to maximum of 5 keywords should be selected not repeating the title but giving the essence of study.

The introduction must answer the following questions: What is known and what is new on the studied issue? What necessitated the research problem, described in the paper? What is your hypothesis and goal?

Material and methods: The objects of research, organization of experiments, chemical analyses, statistical and other methods and conditions applied for the experiments should be described in detail. A criterion of sufficient information is to be possible for others to repeat the experiment in order to verify results.

Results are presented in understandable tables and figures, accompanied by the statistical parameters needed for the evaluation. Data from tables and figures should not be repeated in the text. Tables should be as simple and as few as possible. Each table should have its own explanatory title and to be typed on a separate page. They should be outside the main body of the text and an indication should be given where it should be inserted.

Figures should be sharp with good contrast and rendition. Graphic materials should be preferred. Photographs to be appropriate for printing. Illustrations are supplied in colour as an exception after special agreement with the editorial board and possible payment of extra costs. The figures are to be each in a single file and their location should be given within the text.

Discussion: The objective of this section is to indicate the scientific significance of the study. By comparing the results and conclusions of other scientists the contribution of the study for expanding or modifying existing knowledge is pointed out clearly and convincingly to the reader. Conclusion: The most important consequences for the science and practice resulting from the conducted research should be summarized in a few sentences. The conclusions shouldn't be numbered and no new paragraphs be used. Contributions are the core of conclusions. References:

In the text, references should be cited as follows: single author: Sandberg (2002); two authors: Andersson and Georges (2004); more than two authors: Andersson et al.(2003). When several references are cited simultaneously, they should be ranked by chronological order e.g.: (Sandberg, 2002; Andersson et al., 2003; Andersson and Georges, 2004).

References are arranged alphabetically by the name of the first author. If an author is cited more than once, first his individual publications are given ranked by year, then come publications with one co-author, two co-authors, etc. The names of authors, article and journal titles in the Cyrillic or alphabet different from Latin, should be transliterated into Latin and article titles should be translated into English. The original language of articles and books translated into English is indicated in parenthesis after the bibliographic reference $($ Bulgarian $=\mathrm{Bg}$, Russian $=\mathrm{Ru}$, Serbian $=\mathrm{Sr}$, if in the Cyrillic, Mongolian =
Mo, Greek = Gr, Georgian = Geor., Japanese $=\mathrm{Ja}$, Chinese $=\mathrm{Ch}$, Arabic $=\mathrm{Ar}$, etc.)

The following order in the reference list is recommended:

Journal articles: Author(s) surname and initials, year. Title. Full title of the journal, volume, pages. Example:

Simm G, Lewis RM, Grundy B and Dingwall WS, 2002. Responses to selection for lean growth in sheep. Animal Science, 74, 39-50

Books: Author(s) surname and initials, year. Title. Edition, name of publisher, place of publication. Example:

Oldenbroek JK, 1999. Genebanks and the conservation of farm animal genetic resources, Second edition. DLO Institute for Animal Science and Health, Netherlands.

Book chapter or conference proceedings: Author(s) surname and initials, year. Title. In: Title of the book or of the proceedings followed by the editor(s), volume, pages. Name of publisher, place of publication. Example:

Mauff G, Pulverer G, Operkuch W, Hummel K and Hidden C, 1995. C3variants and diverse phenotypes of unconverted and converted C3. In: Provides of the Biological Fluids (ed. $\mathrm{H}$. Peters), vol. 22, 143-165, Pergamon Press. Oxford, UK.

Todorov N and Mitev J, 1995. Effect of level of feeding during dry period, and body condition score on reproductive performance in dairy cows, IX $X^{\text {th }}$ International Conference on Production Diseases in Farm Animals, September 11-14, Berlin, Germany.

Thesis:

Hristova D, 2013. Investigation on genetic diversity in local sheep breeds using DNA markers. Thesis for PhD, Trakia University, Stara Zagora, Bulgaria, (Bg).

The Editorial Board of the Journal is not responsible for incorrect quotes of reference sources and the relevant violations of copyrights.

\section{Animal welfare}

Studies performed on experimental animals should be carried out according to internationally recognized guidelines for animal welfare. That should be clearly described in the respective section "Material and methods". 


\section{AGRICULTURAL \\ SCIENCE AND TECHNOLOGY}

Volume 9, Number 3

September 2017
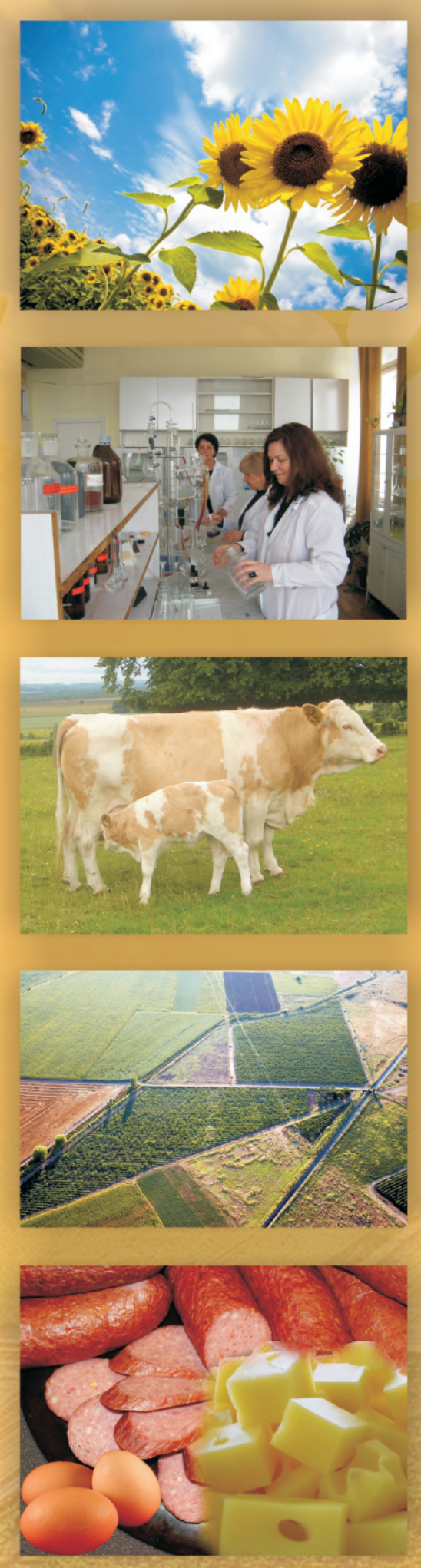

Journal web site: 